\title{
PENERAPAN EMPAT FUNGSI MANAJEMEN PADA \\ PENGELOLAAN PARIWISATA BAHARI BERKELANJUTAN DI \\ DESA JUNGUTBATU, KECAMATAN NUSA PENIDA
}

\author{
I Gede Ngurah Primanda S Rahadiarta \\ Prodi Magister Pariwisata Universitas Udayana \\ Email: adeprimanda90@gmail.com \\ Agung Suryawan Wiranatha \\ Pusat Unggulan Pariwisata, Universitas Udayana \\ Email: agung_suryawan@unud.ac.id \\ I Nyoman Sunarta \\ Universitas Udayana \\ Email: cairns54@yahoo.com
}

\begin{abstract}
Tourism activities in Nusa Penida have experienced a very rapid increase in recent years, mainly in Jungutbatu Village, which is the village where Nusa Penida tourism began around 1970. After the transition from the seaweed farming activities in recent years, now the community relies on the tourism sector. The rapid development of marine tourism and the importance of this to the economy of the community of Jungutbatu Village, requires its management be carried out properly and sustainably. The purposes of this study were to determine the management of marine tourism in Jungutbatu Village through the application of four management functions (Planning, Organizing, Actuating, and Controlling), and to analyze tourist perceptions on the application of sustainable tourism management in Jungutbatu Village. The research approach was descriptive qualitative and data collection methods were observation, interviews, questionnaires and literature study. The results of this study indicated that the management of marine tourism in the Jungutbatu Village was carried out by involving various parties such as the community, entrepreneurs, non-governmental organizations, and the government. The planning, organizing and actuating processes that involved and accommodated the interests of various parties built a sense of responsibility and awareness to participate in the controlling process. Good management led to a good perception of tourists who came to visit, which in turn affected satisfaction and then influenced loyalty to revisit or recommend the marine tourism area of Jungutbatu Village to others.
\end{abstract}

Keywords: management, perception, sustainable tourism, marine protected areas

JUMPA Volume 7, Nomor 2, Januari 2021 669 
I Gede Ngurah Primanda S Rahadiarta, Agung Suryawan Wiranatha, I Nyoman Sunarta

\section{Pendahuluan}

Pariwisata telah menjadi bagian dari kehidupan masyarakat Bali dan memberikan kontribusi besar dalam pembangunan. Peranan pariwisata tersebut dapat dilihat dari kontribusinya pada pendapatan daerah dan penyerapan tenaga kerja. Jika dikelola dengan baik, pariwisata dapat menjadi kekuatan positif untuk memberi keuntungan bagi masyarakat (WTO, 2004). Dalam lima tahun terakhir, jumlah kunjungan wisatawan asing ke Bali mengalami peningkatan hampir 100\%. Pada tahun 2019, Bali dikunjungi oleh 6.275.210 wisatawan asing yang datang baik dari bandara maupun pelabuhan di Bali, bandingkan dengan jumlah kunjungan wisatawan asing di tahun 2013 yang hanya berjumlah 3.278.598 wisatawan (Dinas Pariwisata Provinsi Bali, 2020).

Jumlah kunjungan wisatawan yang terus meningkat dan pertumbuhan ekonomi yang disebabkan oleh pariwisata, membuat tidak hanya Pemerintah Provinsi dan Daerah, tetapi juga seluruh lapisan masyarakatnya memiliki harapan yang besar pada sektor ini. Pada hakikatnya pariwisata diharapkan mampu mengurangi ketimpangan ekonomi di antara daerah yang berbeda, meningkatkan persatuan, dan rasa saling pengertian pada suku yang berbeda, mengurangi urbanisasi, dan meningkatkan konservasi (Anonim, 2011).

Begitu pun yang terjadi di kawasan Nusa Penida, Kabupaten Klungkung. Kecamatan Nusa Penida yang terletak di Kabupaten Klungkung, Provinsi Bali, merupakan satu - satunya Kecamatan kepulauan di Provinsi Bali yang memiliki tiga pulau kecil yaitu Nusa Penida, Nusa Ceningan dan Nusa Lembongan. Ketiga pulau ini memiliki keanekaragaman hayati pesisir dan laut yang cukup tinggi dan merupakan sumber matapencaharian masyarakat setempat terutama dari perikanan dan wisata bahari. Perairan Nusa Penida pada saat ini merupakan salah satu destinasi wisata bahari terfavorit di Bali, dengan aktivitas pariwisata sebagian besar berada di 
Nusa Lembongan, tepatnya Desa Jungutbatu. Perkembangan aktivitas pariwisata di Nusa Lembongan, khususnya pada Desa Jungutbatu, tersebut diakibatkan keragaman potensi wisata bahari yang dimiliki. Potensi tersebut diantaranya wisata hutan mangrove di ujung Utara Desa Jungutbatu, ekosistem terumbu karang miring maupun datar, keanekaragaman fauna laut yang tergolong spesies genting (endangered species), langka dan dilindungi serta berbagai pantai berpasir putih sepanjang pesisir Desa Jungutbatu di Nusa Lembongan (Anonim, 2017).

Menurut data dari Dinas Pariwisata Provinsi Bali tahun 2018 serta Badan Pusat Statistik Kabupaten Klungkung 2019, jumlah kunjungan wisatawan menuju kawasan Nusa Penida mengalami peningkatan hingga 317\% dalam delapan tahun terakhir, yaitu sejumlah 127.836 wisatawan di tahun 2012 menjadi 404.483 wisatawan di tahun 2019. Dari jumlah tersebut sebagian besar mengunjungi kawasan pulau Nusa Lembongan dengan aktivitas pariwisata bahari terbanyak dilakukan di Desa Jungutbatu. Perkembangan pariwisata di Desa Jungutbatu didukung oleh faktor akomodasi, restoran dan yang lainnya. Desa Jungutbatu mendominasi persebaran akomodasi yang terdapat di Kecamatan Nusa Penida. Jumlah akomodasi pariwisata di Desa Jungutbatu pada tahun 2016 berjumlah 1.004 kamar yang terdiri dari hotel berbintang, hotel melati dan pondok wisata. Jumlah ini merupakan 49,32\% dari jumlah total akomodasi pariwisata yang berada di Kecamatan Nusa Penida. Sedangkan jumlah restoran atau rumah makan sebanyak 59 dari 118 restoran atau rumah makan yang tersebar di Kecamatan Nusa Penida, dan mendominasi 22 dari 29 bar yang ada di Kecamatan Nusa Penida. Desa Jungutbatu di Pulau Nusa Lembongan juga memiliki 25 bentuk usaha wisata bahari atau tirta dari 38 usaha sejenis yang terdapat di Kecamatan Nusa Penida. Usaha ini berbentuk antara lain selam, selancar, tur kapal dan olahraga air (Anonim, 2017). 
Besarnya aktivitas pariwisata yang dilakukan di Desa Jungutbatu, Nusa Lembongan menjadikan pengembangan pariwisata sebagai kegiatan ekonomi yang penting bagi masyarakat setempat. Menurut Lockhart dalam Kokkranikal dkk. (2003), karena kontribusinya pada pengembangan ekonomi, pemberdayaan tenaga kerja dan pembangunan secara menyeluruh, masyarakat pulau - pulau kecil sudah sejak lama mengenalkan pariwisata sebagai alternatif ekonomi utama. Berdasarkan pada keadaan tersebut, sudah seharusnya pengelolaan dan pengembangan pariwisata di Nusa Penida, khususnya Desa Jungutbatu, Nusa Lembongan didasarkan pada konsep pariwisata berkelanjutan.

Oleh karena itu, penelitian ini bertujuan untuk mengkaji lebih jauh bagaimana pengelolaan khususnya pada penerapan empat fungsi manajemen (Planning, Organizing, Actuating, Controlling) diterapkan di Desa Jungutbatu, Nusa Lembongan dalam perkembangannya menuju pariwisata bahari yang berkelanjutan. Sedangkan hasil dari pengelolaan yang baik akan dirasakan oleh berbagai pihak yang berkepentingan pada pariwisata bahari di Desa Jungutbatu, utamanya pada wisatawan yang datang berkunjung sebagai pengguna akhir dari aktivitas pariwisata di kawasan tersebut. Baik atau buruknya pengelolaan pariwisata bahari di Desa Jungutbatu yang dirasakan oleh wisatawan akan mempengaruhi kepuasan (satisfaction) yang pada akhirnya akan mempengaruhi loyalitas (loyalty) untuk datang berkunjung kembali (Wiranatha, dkk. 2016). Berlanjutnya kunjungan wisatawan menuju kawasan wisata bahari Desa Jungutbatu dapat diartikan sebagai berkelanjutannya aktivitas pariwisata di sana. Maka dari itu, penting untuk mengetahui bagaimana persepsi wisatawan terhadap pengelolaan, utamanya pada penerapan empat fungsi manajemen, yang dilakukan di kawasan wisata bahari Desa Jungutbatu. 


\section{Metode Penelitian}

Penelitian ini menggunakan pendekatan kualitatif dan dijabarkan secara deskriptif. Pengambilan sampel atau sumber data pada penelitian ini dilakukan secara purposive. Teknik pengumpulan dengan observasi, wawancara dan penyebaran kuesioner, analisa data bersifat deskriptif kualitatif. Jenis data yang digunakan dalam penelitian ini adalah data kualitatif dan kuantitatif, dengan sumber data primer dan sekunder. Hasil dari penelitian ini menganalisis wawancara - wawancara mendalam yang dilakukan terhadap subjek penelitian dan menganalisis kuesioner yang disebarkan pada wisatawan, sehingga dapat memberikan gambaran yang jelas mengenai penerapan empat fungsi manajemen (Planning, Organizing, Actuating, Controlling) pada pariwisata bahari berkelanjutan di Desa Jungutbatu, Nusa Lembongan serta bagaimana persepsi wisatawan pada penerapannya.

Informan dalam penelitian ini ditentukan dengan beberapa kriteria, seperti pihak - pihak yang terkait dengan penentu kebijakan pariwisata (Dinas Pariwisata Provinsi Bali, Kepala UPT KKP Nusa Penida Provinsi Bali); pelaku pariwisata antara lain Ketua Harian Gahawisri Provinsi Bali, Wakil Ketua Gahawisri Provinsi Bali, pengusaha dan pekerja pariwisata bahari di Desa Jungutbatu, Nusa Lembongan; tokoh - tokoh masyarakat seperti Kepala Desa, Ketua Kelompok Pengelola Mangrove, Lembaga Swadaya Masyarakat (Coral Triangle Center) dan masyarakat lokal yang terlibat pada aktivitas pariwisata bahari di Desa Jungutbatu, Nusa Lembongan. Sedangkan responden pada penelitian ini merupakan wisatawan yang secara kebetulan bertemu saat penelitian dilakukan dan melakukan aktivitas wisata bahari yang ada di Desa Jungutbatu, Nusa Lembongan. Wisatawan yang menjadi responden diutamakan para wisatawan yang telah melakukan aktivitas wisata bahari di Desa Jungutbatu, karena hal ini berpengaruh kepada kualitas pemahaman wisatawan dalam memberikan penilaian sesuai dengan persepsi mereka terhadap apa yang 
I Gede Ngurah Primanda S Rahadiarta, Agung Suryawan Wiranatha, I Nyoman Sunarta

mereka lihat dan alami terkait dengan penerapan empat fungsi manajemen dalam pengelolaan yang berkelanjutan di kawasan wisata bahari Desa Jungutbatu.

\section{Hasil dan Pembahasan}

\section{Gambaran Umum Desa Jungutbatu}

Desa Jungutbatu adalah salah satu desa dari 16 desa di Kecamatan Nusa Penida. Secara geografis Desa Jungutbatu berada di sisi Utara dari Pulau Nusa Lembongan, Kecamatan Nusa Penida, Kabupaten Klungkung, Provinsi Bali. Profil Desa Jungutbatu menyebutkan jarak ke Ibu Kota Kecamatan Nusa Penida sekitar 13 km dengan estimasi waktu tempuh satu jam, sedangkan jarak ke Ibu Kota Kabupaten Klungkung sekitar $23 \mathrm{~km}$ dengan estimasi waktu tempuh dua jam. Untuk mencapai kedua tempat tersebut perjalanan ditempuh melalui perjalanan darat dan laut. Menuju Desa Jungutbatu dari Pulau Bali dapat dapat melalui beberapa jalur transportasi laut, yaitu melalui Pelabuhan Kusamba dan Pelabuhan Sanur dengan perahu motor (boat), serta Pelabuhan Benoa dengan kapal cruise (Bounty Cruise atau Bali Hai Cruise). Batas - batas wilayah Desa Jungutbatu yaitu Selat Badung di sebelah Utara dan Barat, Selat Toya Pakeh di sebelah Timur dan Desa Lembongan di sebelah Selatan.

Kondisi perairan Desa Jungutbatu secara umum tergolong perairan dengan tingkat kecuraman dasar laut yang tinggi, walaupun jika dibandingkan dengan perairan sekitar Nusa Penida, kecuraman tersebut relatif lebih landai. Perairan antara Pantai Jungutbatu dan Tanjung Ental memiliki kemiringan dasar laut berkisar 1,8\% 4,3\% sampai pada kedalaman $200 \mathrm{~m}$. Pada bagian Utara antara Tanjung Ental hingga Tanjung Pemaroan, kelandaian dasar laut sampai kedalaman 100 m mencapai 19,5\%, dimana kedalaman ini hanya berjarak 330 m sampai 950 m dari garis pantai (Wiranatha dkk., 2010). 


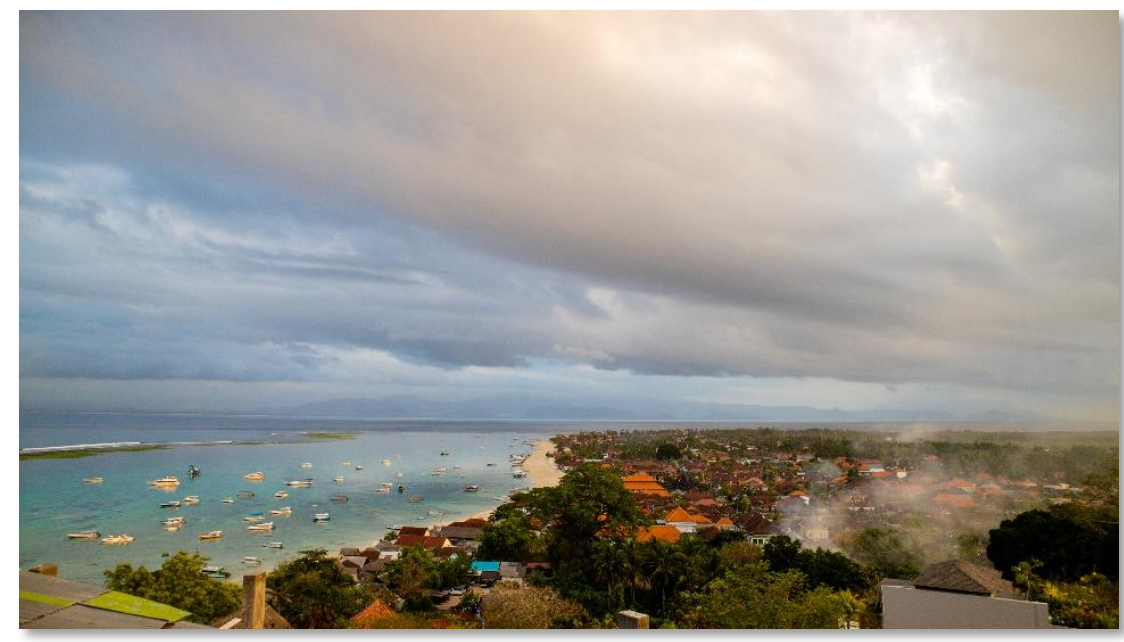

Gambar 1. Desa Jungutbatu, Nusa Lembongan (Primanda, 2019)

Long V. dan Wall G. (1996) menyebutkan pariwisata di Kawasan Nusa Penida dimulai sekitar tahun 1970 dengan dimulainya kedatangan wisatawan - wisatawan ke desa Jungutbatu di Nusa Lembongan untuk berkemah ataupun tinggal di rumah rumah penduduk lokal. Menggunakan kapal - kapal charter wisatawan mulai datang lebih banyak pada tahun 1980 yang diikuti dengan berkembangnya guest house dan bungalow serta jenis - jenis olahraga air seperti surfing dan berbagai perubahan cara berpakaian yang dibawa wisatawan. Pantai - pantai di Desa Jungutbatu pada saat itu lebih diutamakan digunakan untuk kegiatan pertanian rumput laut, seperti menjemur hasil panen maupun tempat menyimpan alat - alat yang digunakan untuk pertanian seperti perahu kecil, tali - tali pengikat ataupun jaring, dan tidak disiapkan atau disajikan untuk kegiatan pariwisata. Namun karena harga yang terus menerus menurun dan ketidakstabilan dari pertanian rumput laut, masyarakat mulai mencari sumber pendapatan alternatif melalui pariwisata. Hingga pada akhirnya saat ini pariwisata menjadi sumber matapencaharian utama masyarakat Desa Jungutbatu. 


\section{Penerapan Empat Fungsi Manajemen}

\section{Planning}

Hasil penelitian yang dilakukan menunjukkan bahwa kawasan bahari Desa Jungutbatu pada awalnya tidaklah disiapkan sebagai kawasan pariwisata, namun perkembangan pariwisata di Desa Jungutbatu yang semakin pesat serta melibatkan berbagai komponen masyarakat, pemerintah serta pengusaha mengharuskan pengelolaannya dapat dilakukan secara optimal sehingga dapat menghasilkan manfaat yang baik secara berkelanjutan. Oleh karena itu, kemudian dilakukan berbagai perencanaan yang dapat mengatur pemanfaatan dan pengelolaan kawasan wisata bahari di Desa Jungutbatu bersifat berkelanjutan. Perencanaan - perencanaan yang dilakukan tersebut turut melibatkan berbagai pihak yang memanfaatkan dan berkepentingan pada pengelolaan pariwisata bahari yang berkelanjutan, diantaranya masyarakat lokal, pemerintah, pengusaha wisata bahari, kelompok masyarakat, lembaga swadaya masyarakat serta akademisi.

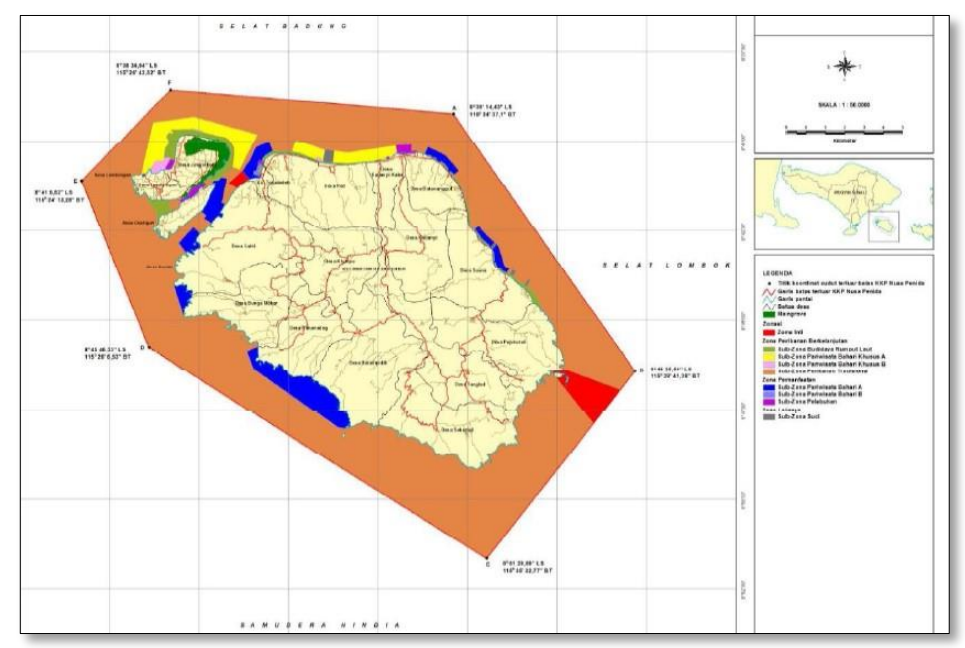

Gambar 2. Peta Zonasi KKP Nusa Penida (UPT KKP Nusa Penida, 2019)

Perencanaan yang paling utama saat ini diterapkan pada kawasan bahari Desa Jungutbatu adalah Rencana Pengelolaan Jangka Panjang dan Zonasi Kawasan Konservasi Perairan (KKP) Nusa Penida, Kabupaten Klungkung, Provinsi Bali. 
Perencanaan itu melibatkan semua stakeholder dalam perancangannya. Berbagai kepentingan dan masukan dikelola dan diaplikasikan pada perencanaan tersebut. Hasil dari proses perencanaan tersebut kemudian menghasilkan pengaturan zona pemanfaatan kawasan bahari di Nusa Penida, termasuk di dalamnya Desa Jungutbatu. Pitana dan Diarta (2009) mengemukakan bahwa penentuan zona pemanfaatan kawasan perairan penting untuk menghindari konflik pemakaian di masa depan.

Kawasan bahari Desa Jungutbatu dibagi berdasarkan zonasi serta waktu dalam penggunaannya. Menurut Liu (1994) dalam Pitana dan Diarta (2009), untuk mencapai tujuan pariwisata yang berkelanjutan baik secara ekonomi, sosial-budaya dan lingkungan, maka pengelola wajib melakukan manajemen atau pengelolaan sumber daya dengan efektif. Salah satunya adalah dengan pemanfaatan sumber daya untuk berbagai kepentingan yang dapat berjalan bersamaan. Perairan Desa Jungutbatu dalam hal ini digunakan sebagai kawasan untuk melakukan kegiatan pariwisata karena keindahan terumbu karangnya. Di sisi lain, terumbu karang yang sehat adalah tempat berkumpulnya ikan - ikan untuk mencari makan, sehingga nelayan mendapat manfaat dengan berlimpahnya ikan yang ada di sana. Walaupun digunakan secara bersamaan, keamanan dan kenyamanan pihak - pihak yang melakukan aktivitas di perairan Desa Jungutbatu haruslah tetap terjamin, dalam hal ini pelaku pariwisata dan nelayan. Hal ini kemudian menjadi dasar untuk mengatur aktivitas pariwisata dan nelayan berdasarkan waktu. Kegiatan pariwisata boleh dilakukan dalam rentang waktu pukul sembilan pagi hingga pukul empat sore, sedangkan untuk kegiatan nelayan dan lainnya boleh dilakukan di luar rentang waktu tersebut.

Pelibatan berbagai pihak dalam perencanaan pengelolaan kawasan pariwisata bahari di Desa Jungutbatu diharapkan dapat membuat penerapannya dilakukan dengan kesadaran penuh serta turut ditaati oleh pihak - pihak yang berkepentingan di sana. Perencanaan tersebut turut serta mengatur tugas - tugas serta peran dari 
pihak - pihak yang terlibat dan berkepentingan di kawasan wisata bahari Desa Jungutbatu atau disebut dengan pengorganisasian (organizing).

\section{Organizing}

Pengorganisasian atau organizing adalah proses kegiatan dalam menyusun struktur organisasi untuk mengetahui job desk atau peran masing - masing pihak yang terlibat. Melalui Keputusan Menteri Kelautan dan Perikanan Nomor 24/KEPMENKP/2014, kawasan bahari Nusa Penida, termasuk di dalamnya Desa Jungutbatu, ditetapkan sebagai Kawasan Konservasi Perairan dalam bentuk Taman Wisata Perairan dengan Unit Pelaksana Teknis Kawasan Konservasi Perairan (UPT KKP) Nusa Penida Provinsi Bali sebagai pengelola utama kawasan bahari di Nusa Penida.

Mengacu pada penetapan tersebut setiap kegiatan yang dilakukan khususnya pada kawasan bahari Desa Jungutbatu, dilakukan dengan berkoordinasi atau sepengetahuan UPT KKP Nusa Penida sebagai pengelola kawasan bahari Nusa Penida. Namun dalam penerapannya masih terdapat tumpang tindih peran antara UPT KKP dan pihak - pihak lainnya yang terlibat dalam pengelolaan kawasan bahari Desa Jungutbatu, utamanya pada permasalahan pengadaan pelatihan Standar Operasional Prosedur pariwisata bagi pekerja - pekerja di sektor pariwisata bahari serta pengadaan fasilitas penunjang aktivitas wisata berkelanjutan di kawasan wisata bahari Desa Jungutbatu seperti pembuatan mooring buoy pada titik - titik di mana perahu ditambatkan saat melakukan aktivitas wisata bahari pada daya tarik wisata yang ada.

Salah satu solusi pembiayaan pengelolaan kawasan bahari Nusa Penida, khususnya pada Desa Jungutbatu adalah dengan mengandalkan pendapatan dari penerapan biaya masuk atau entrance fee yang saat ini telah dilakukan melalui penerapan Perda Kabupaten Klungkung No 5 Tahun 2018 tentang Retribusi Tempat Rekreasi dan Olahraga. Namun, dengan diterapkannya Undang - Undang No. 23 
Tahun 2014 tentang Pemerintahan Daerah, pengelolaan laut yang sebelumnya dibagi antara pemerintah kabupaten (0-4 mil) dan pemerintah provinsi (4-12 mil), kini pengelolaan sepenuhnya menjadi wewenang pemerintah provinsi yaitu mulai 0 mil hingga 12 mil laut, sehingga UPT KKP Nusa Penida pun kini berada di bawah Pemerintah Provinsi Bali dari yang sebelumnya berada di lingkungan Pemerintahan Kabupaten Klungkung. Hal ini menyebabkan biaya yang didapat dari pemberlakuan biaya masuk kawasan tersebut tidak dapat dimanfaatkan secara langsung oleh UPT KKP Nusa Penida sebagai pengelola utama kawasan bahari Nusa Penida.

\section{Actuating}

Dalam penggerakan atau actuating yaitu proses mengikutsertakan sumber daya manusia melalui penyaringan, latihan dan pengembangan tenaga kerja dalam melaksanakan rencana dan pengorganisasian demi mencapai tujuan yang ingin dicapai, berbagai usaha yang dilakukan pihak - pihak yang berkepentingan pada kawasan wisata bahari Desa Jungutbatu kemudian dikelompokkan sesuai dengan tujuan yang ingin dicapai dalam pengelolaan kawasan pariwisata bahari Desa Jungutbatu, yaitu pelestarian lingkungan, pertumbuhan ekonomi serta keharmonisan sosial budaya masyarakat setempat.

Usaha - usaha yang dilakukan untuk mencapai tujuan tersebut antara lain seperti pelatihan mengenai keamanan dalam melakukan aktivitas wisata, tertib dalam penggunaan wilayah atau zona yang sesuai dengan pemanfaatannya, melakukan kegiatan pembersihan pantai serta penanaman mangrove dan transplantasi terumbu karang, termasuk juga usaha dari penyedia wisata untuk dapat memberi kepuasan kepada wisatawan sehingga dapat memberikan kenangan yang baik bagi wisatawan yang kemudian akan berpengaruh kepada keinginan wisatawan untuk berkunjung kembali. 


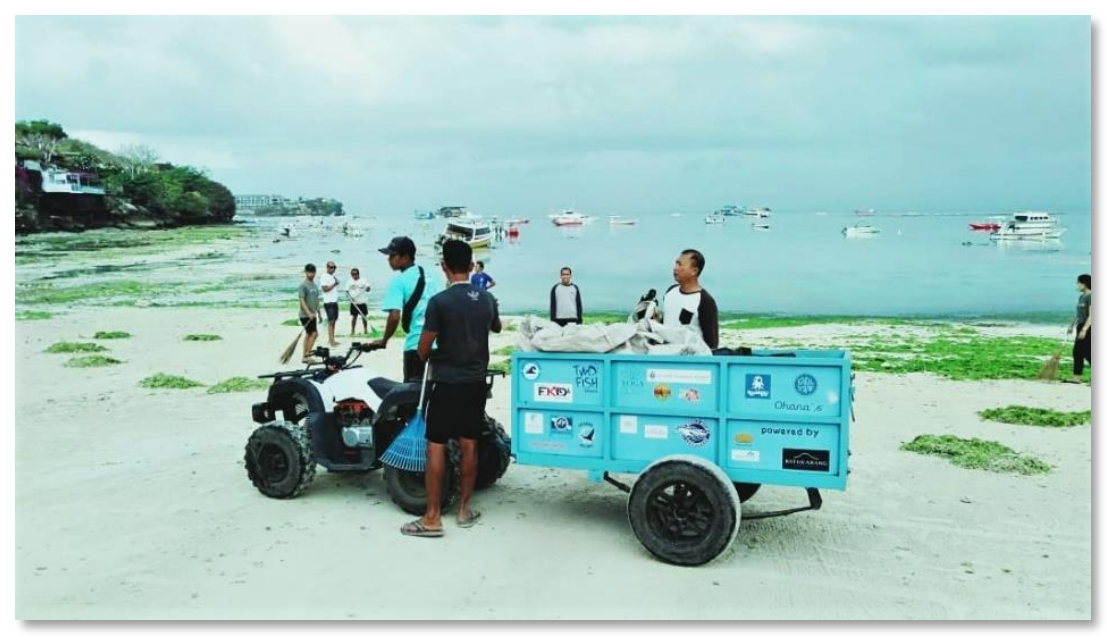

Gambar 3. Kegiatan Bersih - Bersih Pantai Desa Jungutbatu (Primanda, 2019)

Namun seiring dengan bertumbuhnya aktivitas pariwisata, disertai dengan semakin bertambahnya tenaga kerja serta wisatawan yang datang, maka usaha usaha tersebut harus dapat dilakukan dengan berkelanjutan dan konsisten. Hal ini sering kali terkendala dari sisi pendanaan untuk menerapkannya, maka dari itu selain pemanfaatan pembiayaan dari pengenaan biaya masuk kawasan, koordinasi yang baik antara pihak - pihak yang mengelola dan memanfaatkan kawasan bahari Desa Jungutbatu merupakan salah satu hal yang dapat dilakukan untuk menanggulangi permasalahan pendanaan yang dialami.

\section{Controlling}

Tercapainya tujuan dari perencanaan yang dilakukan untuk mencapai pengelolaan pariwisata bahari yang berkelanjutan di Desa Jungutbatu tidak hanya bergantung kepada penggerakan yang baik, tetapi juga kepada pengawasan atau controlling agar penggerakan atau usaha - usaha yang dilakukan teratur, tertib dan terarah.

Terdapat beberapa pengawasan yang dilakukan pada aktivitas pariwisata bahari di Desa Jungutbatu, antara lain pengawasan perizinan dan standar prosedur usaha - usaha pariwisata bahari, pengawasan terhadap kegiatan yang dilakukan di 
kawasan bahari serta penggunaan zonasi sesuai dengan ketentuan Kawasan Konservasi Perairan Nusa Penida. Kegiatan ini dilakukan oleh Pemerintah Provinsi Bali dan Kabupaten Klungkung, pihak pengusaha wisata bahari dan agen perjalanan, serta UPT KKP Nusa Penida selaku pengelola utama kawasan bahari Nusa Penida, di mana Desa Jungutbatu berada.

Meskipun pengawasan yang dilakukan pada kawasan bahari Desa Jungutbatu belum dapat dilakukan secara optimal akibat permasalahan biaya operasional, namun pelibatan masyarakat dalam proses perencanaan, pengelolaan dan pemanfaatan dari kawasan bahari Desa Jungutbatu, membangun kesadaran masyarakat untuk turut serta berpartisipasi dalam pengawasan. Mengingat semakin meningkatnya jumlah kunjungan wisatawan yang melakukan aktivitas wisata di kawasan bahari Desa Jungutbatu, kemungkinan untuk terjadinya pelanggaran baik yang disengaja ataupun tidak disengaja juga akan meningkat. Untuk itu, agar dapat lebih memaksimalkan pengawasan yang dilakukan di kawasan bahari Desa Jungutbatu, maka perlu dilakukan pengalokasian pendanaan yang diterima dari biaya masuk kawasan serta pembentukan Kelompok Pengawas Masyarakat yang dapat melakukan kegiatan pengawasan sehari - hari di lapangan, dibandingkan hanya melakukan pengawasan sekali dalam satu bulan seperti yang dilakukan saat ini.

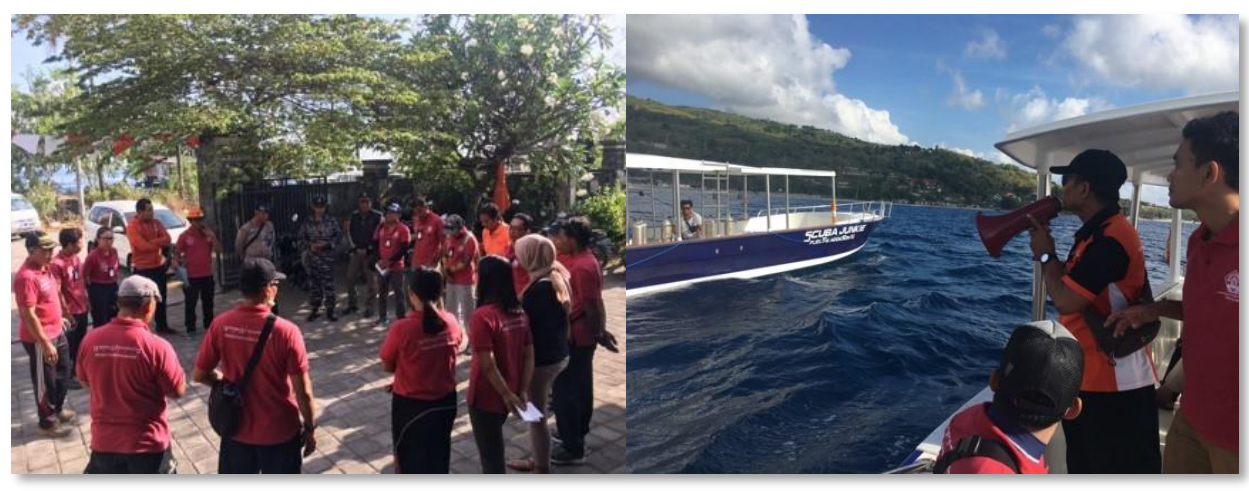

Gambar 4. Kegiatan Pengawasan UPT KKP Nusa Penida

(UPT KKP Nusa Penida, 2019) 


\section{Persepsi Wisatawan}

Persepsi wisatawan terhadap penerapan empat fungsi manajemen pada pengelolaan pariwisata bahari Desa Jungutbatu dianalisis melalui penilaian dari 58 wisatawan yang menjadi responden terhadap 13 indikator yang diberikan. Indikator - indikator tersebut adalah partisipasi masyarakat, partisipasi penyedia jasa wisata, partisipasi pemerintah, pemberdayaan masyarakat lokal, penggunaan sumber daya secara berkelanjutan, daya dukung kawasan dan intensitas pariwisata, monitor dan evaluasi, pelatihan bagi pekerja, pelatihan bagi wisatawan, penyediaan informasi, kebersihan kawasan, keunikan dan keindahan alam, serta keamanan.

Secara keseluruhan penilaian yang diberikan oleh responden mendukung hasil temuan penelitian dalam menjawab Rumusan Masalah 1, sehingga beberapa hal yang dinilai kurang oleh responden perlu mendapatkan perhatian lebih baik. Hal - hal tersebut antara lain peningkatan partisipasi yang lebih baik dari pemerintah terutamanya dalam hal perbaikan dan pembangunan fasilitas pendukung pariwisata bahari seperti pembangunan pelabuhan yang lebih aman dan layak, pembuatan mooring buoy pada lokasi - lokasi snorkeling dan menyelam, sosialisasi mengenai perizinan usaha wisata bahari ataupun pelatihan - pelatihan bagi pelaku usaha wisata bahari di Desa Jungutbatu.

Kebersihan kawasan juga perlu mendapat perhatian lebih baik. Selain permasalahan sampah kiriman pada perairan Desa Jungutbatu yang sering terjadi saat musim penghujan, pengelolaan sampah di Desa Jungutbatu juga tidak dapat dikategorikan baik. Lokasi Tempat Pembuangan Akhir sampah Desa Jungutbatu berada di area mangrove yang tidak terlalu jauh dari lokasi wisata, atau sekitar 800 meter, dengan metode open dumping rentan untuk terbawa air hujan atau angin yang cukup kencang. Baik atau buruknya pengelolaan pariwisata bahari di Desa Jungutbatu yang dirasakan oleh wisatawan akan mempengaruhi kepuasan 
(satisfaction) yang pada akhirnya akan mempengaruhi loyalitas (loyalty) untuk datang berkunjung kembali ataupun merekomendasikan kawasan wisata bahari Desa Jungutbatu kepada orang lain.

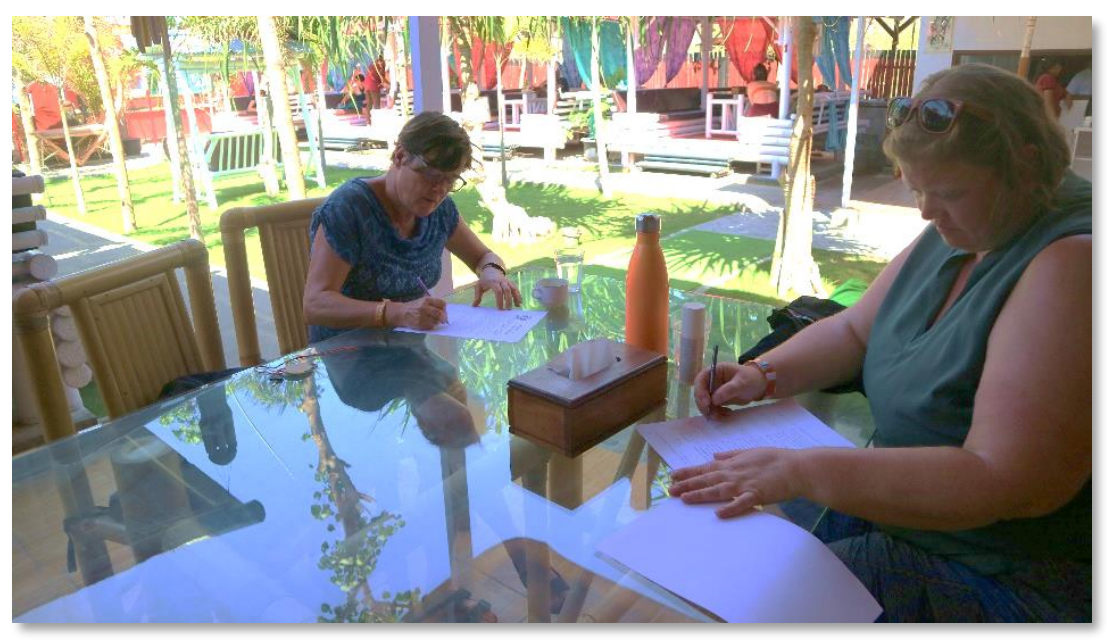

Gambar 5. Wisatawan Mengisi Kuesioner Penelitian (Primanda, 2019)

\section{Simpulan dan Saran}

Proses perencanaan dalam pengelolaan pariwisata bahari di Desa Jungutbatu dilakukan dengan melibatkan berbagai pihak seperti masyarakat, pengusaha, lembaga swadaya masyarakat, serta pemerintah. Proses perencanaan yang baik serta turut mengakomodasi kepentingan berbagai pihak tersebut berkontribusi pada penerapan pengelolaan pariwisata bahari di Desa Jungutbatu yang optimal. Tidak banyak ditemui terjadinya pelanggaran terhadap ketetapan - ketetapan yang disepakati pada saat proses perencanaan. Penggerakan atau usaha - usaha yang dilakukan seperti pelatihan dan sosialisasi berkontribusi pada pemahaman bagi masyarakat tentang pentingnya menjaga kawasan bahari di Desa Jungutbatu agar tetap lestari dan dapat memberi kontribusi dari sisi ekonomi kepada masyarakat secara berkelanjutan. 
Adanya lembaga pengelola kawasan perairan di Desa Jungutbatu, membuat masyarakat memiliki media untuk menyampaikan permasalahan serta keluhan yang mereka miliki dalam pelakasanaan pengelolaan kawasan bahari di sana. Kemampuan untuk dapat menerima aspirasi serta memberikan solusi terhadap permasalahan yang dimiliki oleh masyarakat ini berkontribusi kepada keharmonisan sosial antara masyarakat lokal dan para pihak yang terlibat dalam aktivitas wisata di kawasan bahari Desa Jungutbatu, termasuk di dalamnya pengusaha dan wisatawan.

Persepsi dari wisatawan terhadap indikator - indikator pariwisata bahari berkelanjutan turut mendukung pernyataan serta kondisi pengelolaan pariwisata bahari di Desa Jungutbatu. Meskipun sebagian besar indikator tersebut memiliki persepsi yang baik dari wisatawan, namun beberapa indikator perlu mendapat perhatian lebih seperti peran serta pemerintah serta kebersihan kawasan secara keseluruhan.

Saran yang dapat diberikan agar pariwisata bahari di Desa Jungutbatu dapat berkelanjutan, baik dari sisi kelestarian lingkungan, pertumbuhan ekonomi serta keharmonisan sosial, maka pengelolaan yang saat ini telah dilakukan agar tetap dapat dilakukan dengan baik dan ditingkatkan. Beberapa hal yang harus mendapat perhatian khusus seperti masalah koordinasi antar lembaga pengelola di Desa Jungutbatu, baik lingkungan bahari maupun industri pariwisata, karena dua hal tersebut saling terkait satu dan lainnya. Permasalahan pendanaan untuk kegiatan sosialisasi, pelatihan serta pengawasan juga perlu untuk diperhatikan. Penelitian yang dilakukan oleh LSM CTC tentang bagaimana agar kawasan Nusa Penida, termasuk di dalamnya Desa Jungutbatu, dapat mengelola secara mandiri lingkungan serta ekonominya dengan cara memanfaatkan pendapatan dari biaya masuk kawasan dapat dijadikan sebagai acuan. Permasalahan sampah di kawasan perairan Desa Jungutbatu terutamanya di saat musim penghujan, agar dapat ditangani dengan kerja sama antar pihak pemanfaat kawasan bahari Desa Jungtubatu. Salah satu contohnya, 
penyedia jasa wisata dapat membantu menjaga kebersihan dengan melakukan kegiatan pembersihan di area mereka beroperasi saat sebelum dimulainya aktivitas wisata bahari bersama wisatawan yang menggunakan jasa mereka. Selain permasalahan sampah di kawasan bahari, permasalahan sampah di darat juga perlu mendapat perhatian lebih jauh. Penerapan open dumping serta membakar sampah secara terbuka tidak sesuai dengan aturan penanganan sampah yang baik. Pemerintah perlu bekerja sama untuk setidaknya menyediakan mesin Incenerator yang dapat digunakan untuk membakar timbunan sampah yang ada pada Tempat Pembuangan Akhir.

\section{Ucapan Terima Kasih}

Pada kesempatan ini perkenankanlah penulis mengucapkan terima kasih yang sebesar - besarnya kepada Bapak Dr. Ir. Anak Agung Putu Agung Suryawan Wiranatha, M.Sc., selaku Pembimbing I dan kepada Bapak Dr. Drs. I Nyoman Sunarta, M.Si. selaku Pembimbing II yang dengan penuh perhatian dan kesabaran telah memberikan dorongan, semangat, bimbingan serta saran dalam penyelesaian penelitian ini. Pada kesempatan ini juga penulis ucapkan terima kasih kepada para penguji, Bapak Prof. Made Sudiana Mahendra, M.App.Sc., Ph.D., Bapak Dr. Ida Bagus Gde Pujaastawa, M.A., dan Bapak Dr. I Wayan Suardana, SST.Par., M.Par. atas masukan, saran, sanggahan dan koreksi sehingga penelitian ini dapat terselesaikan dengan baik. Terima kasih juga penulis ucapkan kepada seluruh tenaga pendidik pada Program Studi Magister Pariwisata Universitas Udayana yang telah banyak memberikan pengetahuan, wawasan dan bimbingan serta pegawai administrasi yang telah membantu penulis selama menempuh pendidikan. Tak lupa penulis ucapkan terima kasih kepada keluarga tercinta dan teman - teman yang telah memberikan dukungan moral dan materiil selama penulis menjalankan penelitian ini hingga selesai. 
I Gede Ngurah Primanda S Rahadiarta, Agung Suryawan Wiranatha, I Nyoman Sunarta

\section{Daftar Pustaka}

Anonim. 2004. Indicators of Sustainable Development for Tourism Destinations: A Guidebook. Madrid: World Tourism Organization.

Anonim. 2011. Measuring Employment in the Tourism Industries Beyond a Tourism Satellite Account: A Case Study of Indonesia. Jakarta: International Labour Organization.

Anonim. 2017. Rencana Pengelolaan dan Zonasi Kawasan Konservasi Perairan (KKP) Nusa Penida, Kabupaten Klungkung, Provinsi Bali. Denpasar: Dinas Kelautan dan Perikanan Pemerintah Provinsi Bali.

Bakung, Siti Alyani. 2014. Pengembangan Daya Tarik Wisata Air Terjun Mengkang Sebagai Alternatif Wisata Minat Khusus Di Kabupaten Bolaang Mongondow. Gorontalo: Universitas Gorontalo.

Butler, R. W. 1980. “The Concept of a Tourist Area Cycle of Evolution: Implication for Management of Resources". Canadian Geographer. 24: 1. 5 - 12.

Charlie. 2014. "Collaborative Environmental Governance Networks in Small Indonesian Island Tourism Destinations" (tesis). Melbourne: Victoria University.

Chitapanya, Nirachorn. 2005. "Ecotourism Management for Sustainability in Protected Areas in Thailand" (tesis). Hobart: University of Tasmania.

Cooper, Chris. 2011. Essentials of Tourism. Oxford: Prentice Hall.

Damayanti, Putu Widya. 2016. "Pengelolaan dan Partisipasi Masyarakat pada Daya Tarik Wisata Espa Yeh Panes Natural Hot Spring Resort di Desa Penatahan, Tabanan" (laporan penelitian lapangan). Denpasar: Universitas Udayana.

Dau, Elijah Peceli. 2016. Implementing Sustainable Tourism: Marine Tourism in Fiji. Tourism and Events International Seminar "Implementing Green and Sustainable Tourism". Bali 9 - 10 November.

Geiger, Ottilie. 2017. "The Impact of Stakeholder Relations on the Sustainability of Tourism Development: an Indonesian Case Study" (tesis). Norwegia: The Arctic University of Norway.

Harmini, A. A. 2016. Nusa Lembongan Potential as a Green Tourist Destination. Tourism and Events International Seminar "Implementing Green and Sustainable Tourism". Bali 9 - 10 November.

Heil, Oliver P. dan Helsen, Kristiaan. 2001. “Toward an Understanding of Price Wars: Their Nature and How They Erupt". International Journal of Research in Marketing. 18: 2001. 83-98. 
Inskeep, Edward. 1991. Tourism Planning: An Integrated and Sustainable Development Approach. New York: Van Nostrand Reinhold.

Irianto. 2011. "Dampak Pariwisata Terhadap Kehidupan Sosial dan Ekonomi Masyarakat di Gili Trawangan Kecamatan Pemenang Kabupaten Lombok Utara". Jurnal Bisnis dan Kewirausahaan. 7: 3. 188-194.

Kakazu, Hiroshi. 2011. Sustainable Island Tourism: The Case of Okinawa. Jepang: University of the Ryukyus.

Kokkranikal, J, McLellan, R \& Baum, T. 2003. “Island Tourism and Sustainability: A Case Study of the Lakshadweep Islands". Journal of Sustainable Tourism. 11: 5. 426-447.

Koondoko, Yovanca Yully Feniaty. 2017. “Pengembangan Kepulauan Talaud sebagai Destinasi Wisata Provinsi Sulawesi Utara" (tesis). Denpasar: Universitas Udayana.

Long, V. dan Wall, G. 1996. “Succsessful Tourism in Nusa Lembongan, Indonesia?”. Journal of Tourism Management. 17: 1. 43-50.

Mahaputri, Dwi Reni. 2019. “Strategi Pengembangan Pariwisata Terpadu Desa Bunga Mekar Nusa Penida" (tesis). Denpasar: Universitas Udayana.

Nugroho, S., Arismayanti, N. K., dan Arida, I N. S. 2017. Tren Pariwisata Milenium. Denpasar: Pustaka Larasan.

Page, S. P. 2009. Tourism Management. Managing for Change. Elseiver Ltd.

Pitana, I Gde dan Diarta, I Ketut Surya. 2009. Pengantar Ilmu Pariwisata. Yogyakarta: Penerbit Andi.

Rahardjo, Tjahjono Sofyan. 2002. “Taman Wisata Bahari di Gili Trawangan Lombok” (skripsi). Yogyakarta: Universitas Islam Indonesia.

Solarbesain, Salvinus. 2009. “Pengelolaan Sumberdaya Pulau Kecil untuk Ekowisata Bahari Berbasis Kesesuaian dan Daya Dukung: Studi Kasus Pulau Matakus, Kabupaten Maluku Tenggara Barat, Provinsi Maluku" (tesis). Bogor. Institut Pertanian Bogor.

Soselisa, Alexander. 2006. “Kajian Pengelolaan Sumberdaya Pesisir dan Laut Gugusan Pulau - Pulau Padaido, Distrik Padaido, Kabupaten Biak Numfor, Papua" (tesis). Bogor: Institut Pertanian Bogor.

Suardana, I Wayan. 2013. “Analisis Kebijakan Pengembangan Pariwisata (Intervensi Melalui Kebijakan Pariwisata Berkelanjutan di Bali)" (paper). Denpasar: Universitas Udayana. 
I Gede Ngurah Primanda S Rahadiarta, Agung Suryawan Wiranatha, I Nyoman Sunarta

Sunarta, Nyoman dan Arida, Nyoman Sukma. 2017. Pariwisata Berkelanjutan. Denpasar: Cakra Press.

Terry, George R. dkk. 2000. Dasar-Dasar Manajemen. Jakarta: Bumi Aksara

Ueropean Commission. 2013. Sustainable Tourism for Development: Guidebook. Madrid: World Tourism Organization (UNWTO).

Wiranatha, A. A. P. A. S., dkk. 2010. Perencanaan Pengembangan Pariwisata Bahari Berkelanjutan di Kawasan Nusa Penida. Jakarta: Conservation International Indonesia.

Wiranatha, A. A. P. A. S., Suryawardani, I G. A. O., Bendesa, I K. G., dan Antara, Made. 2016. "Model of Foreign Tourists' Loyalty on Marine Tourism to Visit Bali". Journal of Multidiciplinary Educational Research. Vol. 5, Issues 3.

\section{Profil Penulis}

I Gede Ngurah Primanda S Rahadiarta menyelesaikan pendidikan di Program Studi Magister Pariwisata Universitas Udayana pada tahun 2020. Sebelumnya menyelesaikan pendidikan di Program Sarjana Fakultas Sastra dan Budaya Universitas Udayana dengan mengambil jurusan Sastra Inggris pada tahun 2013. Pernah bekerja di Konsulat India Bali, Indonesia (Desember 2013 - Desember 2014).

Ir. A. A. P. Agung Suryawan W., M.Sc., Ph.D. merupakan Dosen pada Program Studi Magister Pariwisaata yang menyelesaikan pendidikan S1 di Institut Pertanian Bogor, S2 di Griffith University, Australia dan S3 di The University of Queensland, Australia. Bidang keahlian yang ditekuni adalah Perencanaan dan Pengembangan Pariwisata, Pariwisata Berkelanjutan dan Permodelan Sistem Pariwisata.

Dr. Drs. I Nyoman Sunarta, M.Si., menyelesaikan pendidikan S1 di Fakultas Geografi Universitas Gadjah Mada (1986), S2 di Ilmu Lingkungan, Fakultas Geografi Universitas Gadjah Mada (1994) dan pendidikan S3 di Kajian Pariwisata Universitas Udayana (2015). Pernah mengikuti short course Integrated Coastal Zone Planning and Management di James Cook University Townsville, Australia tahun 1997. Pernah 
Penerapan Empat Fungsi Manajemen Pada Pengelolaan Pariwisata Bahari Berkelanjutan...

menjadi sekretaris PPLH Universitas Udayana 1998-2002, pada saat yang sama ditugaskan sebagai anggota tim ahli pembangunan Bali dan Kota Denpasar. Saat ini menjabat sebagai Dekan Fakultas Pariwisata Universitas Udayana periode tahun 2017-2021. 